\title{
PITUITARY ABSCESS WITH UNUSUAL CLINICAL COURSE
}

\author{
Milica Medić Stojanoska $a^{1,2}$, Duško Kozić ch, $^{1,3}$, Mladen Bjelan ${ }^{3}$, Petar Vulekovićn ${ }^{1,4}$, \\ Nada Vučković1,5, Bojan Vuković1, ${ }^{1,6}$ and Branka Kovačev Zavišić1,
}

\begin{abstract}
${ }^{1}$ University of Novi Sad, Faculty of Medicine; ${ }^{2}$ Clinical Center of Vojvodina, Clinical Department of Endocrinology, Diabetes and Metabolic Diseases, Novi Sad; ${ }^{3}$ Oncology Institute of Vojvodina, Diagnostic Imaging Center, Sremska Kamenica; ${ }^{4} \mathrm{Clinical}$ Center of Vojvodina, Clinical Department of Neurosurgery;

${ }^{5}$ Clinical Center of Vojvodina, Clinical Department of Pathology and Histology;

${ }^{6}$ Emergency Center, Novi Sad, Serbia
\end{abstract}

\begin{abstract}
SUMMARY - The aim is to present unusual clinical course and magnetic resonance imaging (MRI) features of pituitary abscess. A 59-year-old man presented with fever, polyuria, polydipsia and marked weight loss within the last two months. Basic endocrinology tests revealed the presence of anterior pituitary dysfunction, associated with central diabetes insipidus and increased levels of inflammatory markers. The presence of expansile sellar lesion, showing restricted diffusion signal pattern compatible with acute pituitary pyogenic abscess was found on MRI. Regression of pituitary abscess was obvious during the next few weeks of parenteral antibiotic treatment. Adequate substitution treatment with L thyroxine, hydrocortisone, testosterone and desmopressin was achieved. Seventeen months later, clinical deterioration associated with recurrent pituitary abscess was confirmed on MRI. Abscess regression was obvious again after conservative treatment. However, control MRI study performed three years after initial scanning revealed the presence of pituitary tumor, most consistent with macroadenoma. Surgical intervention was ordered. Histologic evaluation indicated the presence of fibrotic changes, associated with granulation tissue and rare cellular elements, compatible with chronic inflammation. To the best of our knowledge, there are no studies in the literature describing such a pattern of chronic evolution of pyogenic pituitary abscess with consequent chronic inflammatory changes with granulation tissue proliferation, mimicking macroadenoma.

Key words: Pituitary gland, anterior; Abscess; Pituitary neoplasms; Magnetic resonance imaging; Pituitary hormone deficiency
\end{abstract}

\section{Introduction}

Abscess within the pituitary gland is a rare but life-threatening condition requiring early recognition and treatment to prevent high mortality rate. Clinical presentation is rather nonspecific, ranging from acute to chronic or even indolent course ${ }^{1}$. Hematogenous spread, or direct extension from an infected

Correspondence to: Mladen Bjelan, $M D$, Oncology Institute of Vojvodina, Diagnostic Imaging Center, Put Dr. Goldmana 4, 21204 Sremska Kamenica, Serbia

E-mail:mladen.bjelan@gmail.com

Received January 11, 2016, accepted September 23, 2016 neighboring tissue, in conditions such as paranasal sinusitis, sepsis, meningitis, cavernous sinus thrombophlebitis, pituitary surgery and tooth infection, are the main risk factors for this disease ${ }^{2,3}$. Recurrent meningitis as a presenting manifestation of pituitary abscess is rare but has been reported in the literature ${ }^{4}$. Sometimes, the cause of the disease remains unknown. Pituitary abscess accounts for less than 1\% of pituitary lesions ${ }^{5,6}$. Numerous manuscripts on this topic are available, of which most are case reports ${ }^{2}$. The purpose of this report is to present the unusual clinical course and magnetic resonance (MRI) features of pituitary abscess. 


\section{Case Report}

A 59-year-old man presented with high fever, polyuria and polydipsia. The acute symptoms occurred 4-5 weeks prior to hospitalization, with polyuria and nicturia ( $>5 \mathrm{~L} / 24 \mathrm{~h}$ ), polydipsia ( $>5 \mathrm{~L} / 24 \mathrm{~h}$ ), frontal headaches, feeling of weakness, fatigue, and marked appetite and weight loss $(10 \mathrm{~kg}$ within the last two months). High levels of inflammatory markers were present. Basic endocrinology tests revealed anterior pituitary dysfunction (hypothyroidism, hypocorticism, hypogonadism and growth hormone deficiency) and slightly increased serum prolactin level, associated with central diabetes insipidus (Table 1).

Pituitary region MRI examinations were performed on a $1.5 \mathrm{~T}$ MR scanner using standard MRI protocol, which includes T2W coronal (sequence pa- rameters: TR $3600 \mathrm{~ms}$, TE $120 \mathrm{~ms}$, FOV $14 \times 18 \mathrm{~cm}$, matrix size $380 \times 300$, slice thickness $2 \mathrm{~mm}$ ), as well as T1W coronal and sagittal images (sequence parameters: TR $480 \mathrm{~ms}$, TE $10 \mathrm{~ms}$, FOV $15 \times 18 \mathrm{~cm}$, matrix size $256 \times 224$, slice thickness $2 \mathrm{~mm}$ ) prior and after contrast material application. On the first examination, DWI/ADC in the axial plane (TR $5000 \mathrm{~ms}$, TE $90 \mathrm{~ms}$, FOV 23x23 cm, matrix 192x192, slice thickness $4 \mathrm{~mm}, \mathrm{~b}=0,1000 \mathrm{~mm}^{2} / \mathrm{s}$ ) was added to the routine protocol.

The presence of expansile sellar lesion showing a restricted diffusion signal pattern, compatible with acute pituitary pyogenic abscess was found on MRI (Fig. 1). All bacteriological cultures were negative. Tuberculosis, sarcoidosis, syphilis and Wegener's granulomatosis were excluded as the potential causes of such clinical and radiological features. The patient refused

Table 1. Hormonal profile and inflammatory markers before and after treatment in different phases of the disease

\begin{tabular}{|c|c|c|c|c|c|c|}
\hline \multirow{2}{*}{ Results } & \multicolumn{2}{|c|}{$\begin{array}{l}\text { Pituitary abscess - acute } \\
\text { phase }\end{array}$} & \multicolumn{2}{|c|}{$\begin{array}{l}\text { Recurrent pituitary abscess } \\
\text { (17 months later) }\end{array}$} & \multicolumn{2}{|c|}{$\begin{array}{l}\text { Recurrent pituitary } \\
\text { abscess - chronic phase } \\
\text { (3 years later) }\end{array}$} \\
\hline & $\begin{array}{l}\text { Before } \\
\text { antibiotic } \\
\text { treatment } \\
\end{array}$ & $\begin{array}{l}\text { After } \\
\text { antibiotic } \\
\text { treatment }\end{array}$ & $\begin{array}{l}\text { Before } \\
\text { antibiotic } \\
\text { treatment }\end{array}$ & $\begin{array}{l}\text { After } \\
\text { antibiotic } \\
\text { treatment }\end{array}$ & $\begin{array}{l}\text { Before } \\
\text { surgery }\end{array}$ & $\begin{array}{l}\text { After } \\
\text { surgery }\end{array}$ \\
\hline WBC $\left(4.0-10.0 \times 10^{9} / \mathrm{L}\right.$ & 12.7 & 9.3 & 7.4 & - & 7.09 & 8.9 \\
\hline CRP (0.0-5.0 mg/L) & 93.8 & 11.5 & 190.3 & 0.2 & 8.9 & - \\
\hline Fibrinogen $(1.5-4.5 \mathrm{~g} / \mathrm{L})$ & 6.41 & 4.0 & 6.34 & 3.38 & 3.4 & 3.15 \\
\hline FT4 (9.5-23.1 pmol/L) & 14.4 & 16.8 & 12.1 & 14.8 & 15.6 & 14.8 \\
\hline FT3 (2.6-6.5 pmol/L) & 4.2 & - & - & - & - & - \\
\hline TSH (0.35-4.49 mU/L) & 0.007 & - & - & - & - & - \\
\hline PRL (4.6-21.4 ng/mL) & 21.5 & - & 9.6 & - & 2.5 & 2.1 \\
\hline $\mathrm{ACTH}$ (to $46 \mathrm{pg} / \mathrm{mL}$ ) & 6.0 & - & - & - & - & - \\
\hline Cort $8 \mathrm{~h}(171-650 \mathrm{nmol} / \mathrm{L})$ & 2.6 & - & - & - & - & - \\
\hline Cort $18 \mathrm{~h}(64-330 \mathrm{nmol} / \mathrm{L})$ & 1.9 & - & - & - & - & - \\
\hline FSH (1.-2.4 IU/L) & 2.0 & - & - & - & - & - \\
\hline LH (1.7-8.6 IU/L) & 0.12 & - & - & - & - & - \\
\hline Testo (9.9-27.8 nmol/L) & 3.2 & 16.2 & - & - & 15.2 & - \\
\hline $\mathrm{GH}(0.07-2.5 \mathrm{mcg} / \mathrm{L})$ & 0.27 & - & - & - & - & - \\
\hline IGF-1 (118-3144 mcg/L) & 60 & - & - & - & 60 & - \\
\hline P Osm (270-300 mOsm/kg) & 295.0 & - & - & - & 285 & 283 \\
\hline U Osm (30-1300 mOsm $/ \mathrm{kg})$ & 86 & - & - & - & 568 & 722 \\
\hline $\mathrm{S} \mathrm{Na}(135-155 \mathrm{mmol} / \mathrm{Ll})$ & 156 & 140 & - & - & 143 & 145 \\
\hline
\end{tabular}

$\mathrm{WBC}=$ white blood cell count $\mathrm{CRP}=\mathrm{C}$-reactive protein; FT4 = free thyroxine; FT3 = free triiodothyronine; TSH = thyroidstimulating hormone; PRL = prolactin; ACTH = adrenocorticotropic hormone; Cort = cortisol; FSH = follicle-stimulating hormone; $\mathrm{LH}=$ luteinizing hormone; Testo = testosterone; $\mathrm{GH}=$ growth hormone; IGF-1 = insulin-like growth factor 1; P Osm = plasma osmolarity; $\mathrm{U}$ Osm = urine osmolarity; $\mathrm{S} \mathrm{Na}=$ serum sodium concentration 


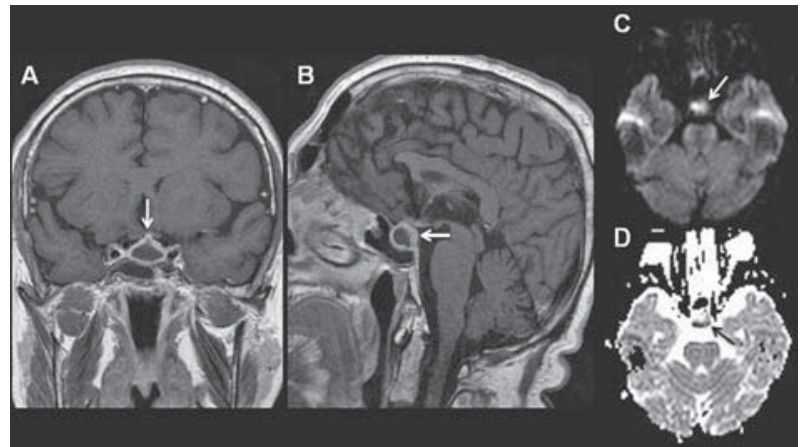

Fig. 1. Coronal $(A)$ and sagittal $(B) T 1 W$ images after administration of paramagnetic contrast agent revealed expansile pituitary mass with rim enhancement (arrows in $A$ and B). Pituitary mass shows restricted diffusion evident on axial DWI (arrow in C) and corresponding $A D C$ map (arrow in D).

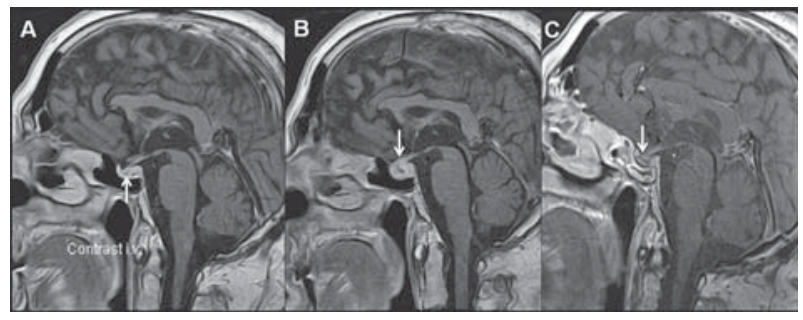

Fig. 2. T1W image with contrast agent showing regression (arrow in $A$ ), followed by recurrence (arrow in B) of pituitary abscess. Abscess regression after conservative treatment several weeks later (arrow in $C$ ).

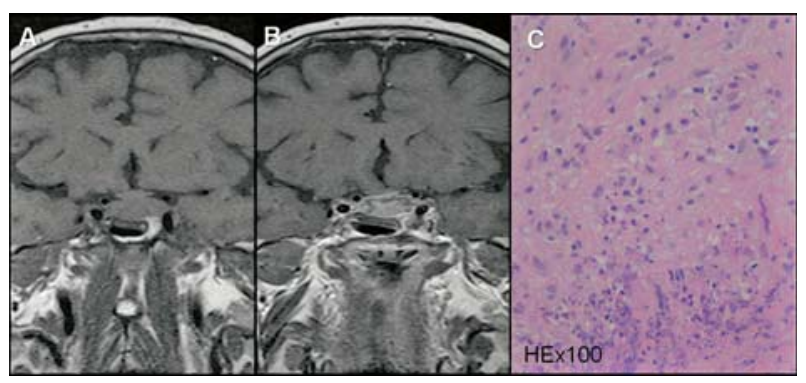

Fig. 3. T1W images without $(A)$ and with (B) contrast agent three years later revealed the presence of pituitary tumor, most consistent with macroadenoma. Histologic evaluation: pituitary tissue fragment mainly replaced by connective tissue and chronic inflammatory infiltrate with less common granulocytes $(C)$.

pituitary surgery. Parenteral antibiotic treatment was administered (meropenem, vancomycin, ciprofloxacin) and regression of pituitary abscess was obvious on re- peated MRI study (Fig. 2A). Adequate substitution treatment with $\mathrm{L}$ thyroxine $(100 \mu \mathrm{g} / 24 \mathrm{~h})$, hydrocortisone $(20 \mathrm{mg} / 24 \mathrm{~h})$, testosterone $(250 \mathrm{mg} / 24 \mathrm{~h})$ and desmopressin $(10 \mu \mathrm{g} / 24 \mathrm{~h})$ was achieved. This was followed by complete regression of diabetes insipidus 6 months later. Seventeen months later, clinical deterioration associated with recurrent pituitary abscess was confirmed on MRI (Fig. 2B). Abscess regression was again obvious after conservative treatment several weeks later (Fig. 2C). However, control MRI study performed because of headaches three years after initial scanning revealed the presence of pituitary tumor, most consistent with macroadenoma (Fig. 3A and B) with panhypopituitarism (Table I). Surgical intervention was ordered. Histologic evaluation found the presence of fibrotic changes, with large amount of granulation tissue, associated with rare cellular elements, compatible with chronic inflammation (Fig. $3 \mathrm{C})$. The patient was discharged in improved clinical status and recommendation for continuation of hormone replacement therapy.

\section{Discussion and Conclusion}

Magnetic resonance imaging diagnosis of pituitary abscess should be suspected in patients with sellar cystic mass showing peripheral rim enhancement after contrast administration. However, the specificity of such a pattern is not extremely high, since other pituitary disorders may have similar appearance on conventional images ${ }^{7}$. Advanced imaging techniques such as diffusion imaging have markedly improved the specificity of MRI in differentiation between pituitary abscesses and tumors, since increase in diffusion signal and decrease of apparent diffusion coefficient are typical for abscesses, whereas necrotic masses show decreased signal on diffusion sequence and elevation of apparent diffusion coefficient ${ }^{2}$. Such a pattern was also evident in our patient on the initial study. The largest series of patients with hypophyseal abscess, i.e. 33, 29 and 24, have been reported by Liu et al., Zhang et al. and Vates et al., respectively ${ }^{8-10}$. The most common clinical presentations are diabetes insipidus and the triad of headache, visual disorders and hypopituitarism $^{2,8,11}$. Complete recovery rate was around $60 \%$ in patients where adequate treatment was administered, while $30 \%$ of patients showed incomplete recovery with visual or endocrine impairment ${ }^{2,10}$. However, lethal outcomes have also been reported ${ }^{1}$. 
Surgery is an effective treatment modality in achieving decompression with associated resolving of headache and visual deficits in patients with pituitary abscess. Most patients require life-long replacement with anterior pituitary hormones, since surgery has no significant effect on improving the preexisting endocrine defects ${ }^{12,13}$.

Most space occupying lesions of the sellar region are neoplastic in nature (pituitary adenomas, craniopharyngiomas, and less frequently meningiomas) ${ }^{14,15}$. In approximately $8 \%$ of patients present with sellar region mass lesions of non-neoplastic nature, mainly infectious or inflammatory disorders, cysts and hyperplasia ${ }^{15}$. Hyperplasia can result in doubling of the pituitary size ${ }^{16}$. Also, space occupying lesions involving sellar region include vascular (aneurysms) and bony processes (especially fibrous dysplasia). Incomplete healing associated with proliferation of fibrous-granulation tissue, mimicking tumor, was evident in our patient. Recurrence of pituitary abscess has been reported in the literature ${ }^{7,17}$. However, to the best of our knowledge, there are no clinical or imaging reports of pituitary abscess recurrence with later consequent presence of marked amount of fibrous and granulation tissue associated with rare cellular elements, mimicking tumor. No granulomas were documented in our patient. Tumor mimicker in sellar region could be hypophysitis. This disease is classified into primary and secondary forms. Primary form is typically autoimmune, granulomatous, necrotizing or xanthomatous in nature $^{18}$. Secondary form is associated with other pituitary disorders such as tumors and Rathke's cyst, or systemic diseases such as tuberculosis, syphilis, sarcoidosis and Wegener's granulomatosis ${ }^{12,19-21}$. Other tumor mimickers could be hemorrhages within the pituitary gland, or enlargement of hypophysis in hypothyroidism ${ }^{16}$. Our report reflects a new type of tumor mimicker, consistent with granulation tissue proliferation. In inflammatory and infectious diseases, sella turcica is usually not expanded. In our patient, it was not expanded on initial examination, however, the enlargement that is typical in neoplastic diseases (benign and malignant), was evident on the last examination. Most likely, long-standing, chronic infectious processes may also be associated with sella turcica enlargement, as in our patient, mimicking tumor. Although the pituitary is a well vascularized organ and a high concentration of antibiotics can be expected in pituitary tissue, intro- ducing antibiotic therapy without reliable evidence for the causative agent and antibiotic sensitivity report may imply the risk of disease recurrence.

Acknowledgment. This work was supported by grant 114-451-2216/2016-2, Provincial Secretariat for Higher Education and Scientific Research, Antonomous Province of Vojvodina, Republic of Serbia.

\section{References}

1. Kotani H, Abiru H, Miyao M, Kakimoto Y, Kawai C, Ozeki M, et al. Pituitary abscess presenting a very rapid progression: report of a fatal case. Am J Forensic Med Pathol. 2012;33(3):280-3. DOI: http://dx.doi.org/10.1097/PAF.0b013e3182557dcf

2. Altas M, Serefhan A, Silav G, Cerci A, Coskun KK, Elmaci I. Diagnosis and management of pituitary abscess: a case series and review of the literature. Turk Neurosurg. 2013;23(5):611-6. DOI: http://dx.doi.org/10.5137/1019-5149.JTN.7443-12.2

3. Dalan R, Leow MK. Pituitary abscess: our experience with a case and a review of the literature. Pituitary. 2008;11(3):299-306.

4. Chelaifa K, Bouzaidi K, Azaiz O, Ridene I, Ben Messaoud M, Slim R. Tuberculous meningitis with pituitary abscess. J Neuroradiol. 2003;30(3):188-91.

5. Dutta P, Bhansali A, Singh P, Kotwal N, Pathak A, Kumar Y. Pituitary abscess: report of four cases and review of literature. Pituitary. 2006;9(3):267-73.

6. Jain KC, Varma A, Mahapatra AK. Pituitary abscess: a series of six cases. Br J Neurosurg. 1997;11(2):139-43.

7. Bladowska J, Bednarek-Tupikowska G, Sokolska V, Czapiga E, Czapiga B, Sasiadek M. Unusual presentation of recurrent pituitary abscess. A case report and literature review. Neuroradiol J. 2010;23(5):600-6.

8. Liu F, Li G, Yao Y, Yang Y, Ma W, Li Y, et al. Diagnosis and management of pituitary abscess: experiences from 33 cases. Clin Endocrinol (Oxf). 2011;74(1):79-88. DOI: http://dx.doi. org/10.1111/j.1365-2265.2010.03890.x

9. Zhang X, Sun J, Shen M, Shou X, Qiu H, Qiao N, et al. Diagnosis and minimally invasive surgery for the pituitary abscess: a review of twenty-nine cases. Clin Neurol Neurosurg. 2012; 114(7):957-61. DOI: http://dx.doi.org/10.1016/j.clineuro.2012.02.020

10. Vates GE, Berger MS, Wilson CB. Diagnosis and management of pituitary abscess: a review of twenty-four cases. J Neurosurg. 2001;95(2):233-41.

11. Zhu H, Gu XM, Hong J, Shen FX. Successful treatment of pituitary abscess with intravenous antibiotics: a case report and literature review. Genet Mol Res. 2014;13(4):10523-8. DOI: http://dx.doi.org/10.4238/2014.December.12.14

12. Caturegli P, Newschaffer C, Olivi A, Pomper MG, Burger PC, Rose NR. Autoimmune hypophysitis. Endocr Rev. 2005;26(5): 599-614. 
13. Su SB, Zhang DJ, Yue SY, Zhang JN. Primary granulomatous hypophysitis: a case report and literature review. Endocr J. 2011;58(6):467-73.

14. Saeger W, Ludecke DK, Buchfelder M, Fahlbusch R, Quabbe HJ, Petersenn S. Pathohistological classification of pituitary tumors: 10 years of experience with the German Pituitary Tumor Registry. Eur J Endocrinol. 2007;156(2):203-16.

15. Saeger W. Space occupying processes of the sellar region with emphasis on tumor-like lesions. Pathologe. 2003;24(4):247-54.

16. Saigal G. Re: Primary hypothyroidism mimicking a pituitary macroadenoma: regression after thyroid hormone replacement therapy. Pediatr Radiol. 2009;39(4):417. DOI: http://dx.doi. org/10.1007/s00247-009-1153-5

17. Danilowicz K, Sanz CF, Manavela M, Gomez RM, Bruno OD. Pituitary abscess: a report of two cases. Pituitary. 2008;11(1): 89-92.
18. Shi J, Zhang JM, Wu Q, Chen G, Zhang H, Bo WL. Granulomatous hypophysitis: two case reports and literature review. J Zhejiang Univ Sci B. 2009;10(7):552-8. DOI: http://dx.doi. org/10.1631/jzus.B0820355

19. Gundgurthi A, Kharb S, Garg MK, Brar KS, Bharwaj R, Gupta $\mathrm{S}$, et al. Combined granulomatous and lymphocytic hypophysitis presenting as pituitary incidentaloma in a middle-aged woman. Indian J Endocrinol Metab. 2012;16(5):846-9. DOI: http://dx.doi.org/10.4103/2230-8210.100680

20. Sautner D, Saeger W, Ludecke DK, Jansen V, Puchner MJ. Hypophysitis in surgical and autoptical specimens. Acta Neuropathol. 1995;90(6):637-44.

21. Kruljac I, Sulentić P, Cigrovski-Berković M, Petrović V, Pećina HI, Čerina V, et al. Hypopituitarism caused by pituitary metastasis of supraglottic laryngeal carcinoma: case report. Acta Clin Croat. 2010;49(3):347-51.

Sažetak

\title{
PITUITARNI APSCES NEUOBIČAJENOG KLINIČKOG TIJEKA
}

\author{
M. Medić Stojanoska, D. Kozić, M. Bjelan, P. Vuleković, N. Vučković, B. Vuković i B. Kovačev Zavišić
}

Cilj rada je prikaz neuobičajenog kliničkog tijeka i magnetsko-rezonantnih (MR) karakteristika pituitarnog apscesa. Bolesnik je bio 59-godišnji muškarac s groznicom, poliurijom, polidipsijom i gubitkom tjelesne mase u posljednja dva mjeseca. Osnovni endokrinološki testovi ukazali su na poremećaj funkcije adenohipofize, udružen s centralnim insipidnim dijabetesom i povišenom razinom upalnih biljega. Pregled pomoću MR je otkrio ekspanzivnu leziju u selarnoj regiji sa znacima restrikcije difuzije, nalaz kompatibilan s pituitarnim apscesom. Nakon primjene antibiotika tijekom sljedećih nekoliko tjedana došlo je do regresije apscesa, a odgovarajuće nadomještanje hormona postignuto je primjenom L-tiroksina, hidrokortizona, testosterona i dezmopresina. Sedamnaest mjeseci kasnije uočeno je pogoršanje kliničkog stanja s opetovanim pituitarnim apscesom, što je potvrđeno pomoću MR. Nakon primijenjene terapije došlo je do ponovne regresije apscesa. Međutim, kontrolni pregled pomoću MR tri godine nakon prvog otkrio je prisustvo pituitarnog tumora s obilježjima makroadenoma, zbog čega je provedena kirurška intervencija. Patohistološka analiza je dokazala prisustvo fibroze udružene s granulacijskim tkivom, rijetkim staničnim elementima, karakteristično za kroničnu upalu. U literaturi ne postoje studije koje prikazuju kroničnu evoluciju pituitarnog apscesa s kroničnim upalnim promjenama koje oponašaju makroadenom.

Ključne riječi: Hipofiza, prednja; Apsces; Neoplazma hipofize; Magnetska rezonancija; Deficit hormona hipofize 